\title{
Free Radicals Scavenging Activity and Oxidative DNA Damage Protecting Property of Methanol Extract from Honeycrisp Apple
}

\author{
Williams Kweku Darkwah*, Matthew Nkoom
}

\section{Williams Kweku Darkwah*, Matthew Nkoom}

Key Laboratory of Integrated Regulation and Resource Development on Shallow Lakes, Ministry of Education, Environmental Engineering Department, College of Environment, Hohai University, Nanjing, CHINA.

\section{Correspondence}

Williams Kweku Darkwah

Key Laboratory of Integrated Regulation and Resource Development on

Shallow Lakes, Ministry of Education,

Environmental Engineering Department,

College of Environment, Hohai University,

Nanjing, CHINA.

Phone no: +8615295782807

E-mail: williams.darkwah@stu.ucc.edu.gh, williamsdarkwakwaku@yahoo.com

History

- Submission Date: 20-02-2019;

- Review completed: 12-04-2019;

- Accepted Date: 26-04-2019.

DOI : 10.5530/pj.2019.11.110

Article Available online

http://www.phcogj.com/v11/i4

Copyright

(C) 2019 Phcogj.Com. This is an openaccess article distributed under the terms of the Creative Commons Attribution 4.0 International license.

\begin{abstract}
Objectives: This research reports the qualitative phytochemical constituents and considers the in vitro free radicals scavenging activities based on DPPH and nitric oxide assays and oxidative DNA damage protection activity of methanol extract from Honeycrisp apple. The foremost interest for this research was to use standard measures to determine nitric oxide scavenging activity, DPPH-scavenging activity and DNA damage protecting activity to assess the antioxidant potential of methanol extract from the apple. Materials and Methods: Concentrations of apple extracts with the intervals $20 \mu \mathrm{g} / \mathrm{ml}$ to $100 \mu \mathrm{mg} / \mathrm{ml}$ were prepared and mixed with suitable volumes of reagents and the corresponding absorbances read at the respective wavelength. Results: The outcomes of this research specify that methanol extract of Honeycrisp apple contain multiple phytochemical compounds that can expertly shield the body against oxidative stress caused by free radicals and might then be used as a source of potent natural antioxidant compounds. The $\mathrm{IC}_{50}$ values of methanol extract from Honeycrisp apple varied from 10.30 to $36.29 \mu \mathrm{g} / \mathrm{ml}$ which indicates the high radical scavenging activity of the sample. Conclusion: The DNA damage defensive potential of the extracts was also revealed, which could be used in cancer inhibition.
\end{abstract}

Key words: Honeycrisp apple, Free radicals, DNA damaging, Nitric oxide, Phytochemicals, $\mathrm{DPPH}$.

\section{INTRODUCTION}

Active cells in living organisms are always wideopened to a range of challenges that work oxidative pressure in the system. Oxidative trauma rises in a living configuration once an augmented contact to oxidants, a decline happening the antioxidant ability of the system, or both. This is often associated with the production of reactive oxygen species (ROS), which consists of free radicals, which are intensely connected in the pathology of diseases, for instance cancer, rheumatoid arthritis, liver cirrhosis and arteriosclerosis also in degenerative processes associated with old age. ${ }^{1-18}$

Most Scientists doubted harmfulness of some artificial composites used in food and this upturned the interest in natural products. ${ }^{11-31}$ Some productions, those in line with food additive production, cosmetics and pharmaceuticals, also have put up an augment on their struggles in the fabrication of bioactive composites mostly obtained from natural products synthesis. Free radical scavenging composites are well known to obstruct free radicals and upturn duration by delaying the course of lipid peroxidation..$^{16,17}$ Hence, this called for the need for isolating other forms of natural and nontoxic sources of food antioxidants.

Currently, research efforts have been dedicated to the studies on structure and physiological role of apple because of its recognized health remunerations. ${ }^{3,5,13,22,28,32}$ The Scientific name of apple is Malus domestica L. Borkh. The healthprotective possessions of apples such as honeycrisp are attributed to phytochemicals, such as phenols that may reduce the menace of obesity, diabetes, cardiovascular disease and cancer through protection against oxidative damage. ${ }^{10,26,33,34}$

The prime purpose of this research was to determine the qualitative phytochemical constituents and consider the in vitro free radicals inhibitory activities based on DPPH and nitric oxide assays and oxidative DNA damage protection activity of methanol extract from honeycrisp apple. This work will provide a basis for the use of honeycrisp apple as a functional food or natural medicinal ingredient that can replace synthetic compounds.

\section{MATERIALS AND METHODS}

\section{Plant material}

Ripe Honeycrisp apple fruits were obtained from 10-year-old apple trees implanted on the rootstock in the botanical garden, University of Cape Coast, Ghana in October 2015. The defect-free apples were collected. The taxonomic character of the apple was confirmed by a plant taxonomist at the Department of Botany, University of Cape Coast, Ghana. The apple sample was then washed under running tap water to eradicate undesirable filth and other external materials. The sample was look - dried underneath shade till the absence of moisture. The dried sample was grounded into powder by the help a blender. 


\section{Preparation of plant extracts}

\section{Methanol extraction}

The methanol extract was prepared by soaking $60 \mathrm{~g}$ of powdered sample of Honeycrisp apple in $210 \mathrm{ml}$ of methanol (70\%) for $72 \mathrm{~h}$ at room temperature $\left(35^{\circ} \mathrm{C}\right)$. The mixture was then filtered using Whatman filter paper No 1 . The filtrate was intense under a low pressure using rotary evaporator at temperature of $46^{\circ} \mathrm{C}$. The follow-on extract was weighed and stored in airtight bottles at room temperature for further used.

yield $(\%)=\left(\frac{A_{1}}{A_{0}}\right) \times 100$, Where $\mathrm{A}_{0}$ was the mass of the sample and $A_{1}$ was the mass of the crude extract.

\section{Phytochemical screening (qualitative analysis)}

Phytochemical selection of the methanolic extracts of Honeycrisp apple was carried out as per the standard protocol ${ }^{6,718,33}$ to determine the presence of glycosides, terpenoids, flavonoids, carbohydrates, protein, alkaloids, phenolic compounds, tannins, saponins and Phytosterols.

\section{1, 1 Diphenyl-2, picrylhydrazine (DPPH) antioxidant activity}

This was measured in accordance with the method of Shimada, et al. ${ }^{29}$ Each reaction mixture contained $1.0 \mathrm{~mL}$ of a specific concentration $(20-100 \mu \mathrm{g} / \mathrm{mL})$ of methanol extract of Honeycrisp apple and standards (ascorbic acid and tannic acid) and $1.0 \mathrm{~mL}$ of DPPH solution $(0.135$ $\mathrm{mM})$. The mixture was shaken vigorously and left in the dark for 30 mins. The absorbance was measured at $517 \mathrm{~nm}$ against a reagent blank. The percentage ability for scavenging DPPH free radical by the sample was designed in accordance with to the equation:

DPPH scavenging activity $(\%)=\left(\frac{A_{0}-A_{1}}{A_{0}}\right) \times 100$, Where $\mathrm{A}_{0}$ was the blank absorbance and $\mathrm{A}_{1}$ was the extract absorbance or the standard absorbance

\section{Nitric oxide scavenging activity}

Nitric oxide free radical inhibition was measured in accordance with the technique designated by Jagetia, et al. ${ }^{19} \mathrm{~A}$ volume of $2 \mathrm{ml}$ sodium nitroprusside in phosphate buffer $(0.02 \mathrm{M}, \mathrm{pH} 7.4)$ was varied with diverse concentrations $(20-100 \mu \mathrm{g} / \mathrm{ml})$ of each methanol extract of Honeycrisp apple and standards (ascorbic acid and tannic acid). The feedback combination was retained at $25^{\circ} \mathrm{C}$ for $2 \mathrm{hrs}$. Subsequently, 1.5 $\mathrm{ml}$ of Griess reagent [1\% sulphanilamide, 2\% O-phosphoric acid and $0.1 \%$ of $\mathrm{N}$-(1- naphthyl) ethylenediamine dihydrochloride] was added. The absorbance measurement was taken at $540 \mathrm{~nm} 30$ mins afterwards against a phosphate buffer blank. The percentage inhibition of nitric oxide radicals by extracts and standards was extrapolated using the formula:

scavenging activity $(\%)=\left(\frac{A_{0}-A_{1}}{A_{0}}\right) \times 100$, Where $\mathrm{A}_{0}$ was the blank absorbance and $A_{1}$ was the extract absorbance or the standard absorbance.

\section{Genomic DNA extraction}

Cowpea seeds (Vigna unguiculata) purchased from Kotokuraba market, Cape Coast, in the Central region of Ghana, were sowed and allowed to germinate. After 1 week, the leaves of the germinated seeds were collected. Genomic DNA was extracted adopting a modified cetyltrimethylammonium bromide protocol described by Darkwah, et $a l .{ }^{7,36}$ The integrity of the extracted DNA was tested by running a $5 \mu \mathrm{l}$ DNA sample on gel electrophoresis at $100 \mathrm{~V}$ for $1 \mathrm{~h} 20 \mathrm{mins}$. The purity was also determined by measuring the absorbance of each DNA sample at $260 \mathrm{~nm}$ and $280 \mathrm{~nm}$ and the ratio computed. A ratio $\geq 1.8 \leq 2.0$ implied a pure nucleic acid sample; however, a ratio $<1.8$ indicates impurity depicting the presence of protein. Meanwhile, a ratio $>2.0$ indicates that the samples were contaminated with phenol or chloroform. To standardize the samples, the concentration of the DNA was also determined using the formula:

DNA concentration $(\mu \mathrm{g} / \mathrm{ml})=\left(\frac{A_{260} * D * 50 \mu \mathrm{g} / \mathrm{ml}}{1000}\right)$

Where $A_{260}$ represents the absorbance at $260 \mathrm{~nm}$ and $\mathrm{D}$ is the dilution factor. The determination of the concentrations enabled the standardization to $100 \mathrm{ng} / \mu \mathrm{l}$. Samples that were highly concentrated were diluted with sterile Tris-EDTA (TE) buffer, whereas those with lower concentrations, the extraction process was repeated.

\section{DNA damage protective potential of methanolic of Honeycrisp apple}

DNA protection potential of the extracts were evaluated using cowpea (Vigna unguiculata) genomic DNA. DNA was extracted according to the cetyl trimethyl-ammonium bromide (CTAB) technique as designated by Doyle and Doyle. ${ }^{79}$ Oxidative impairment to DNA was prompted using hydroxyl free-radical generating system $\left(\mathrm{H}_{2} \mathrm{O}_{2} / \mathrm{UV}\right)$ which was also pronounced by Russo, et al. ${ }^{27}$ in the existence of the extracts. Briefly, $10 \mu \mathrm{l}$ aliquot of cowpea DNA was added into microfuge tubes containing $10 \mu \mathrm{l}$ of different concentrations of methanol extracts $(0.02$, 0.1 and $10 \mathrm{mg} / \mathrm{ml})$ and $10 \mu \mathrm{l}$ of $30 \% \mathrm{H}_{2} \mathrm{O}_{2}$. Ascorbic acid $(10 \mathrm{mg} / \mathrm{ml})$ was used as a constructive control in the absence of the Honeycrip apple sample. The normal control contained only the DNA extract while the destructive control contained DNA plus $\mathrm{H}_{2} \mathrm{O}_{2}$. The tubes were UV irradiated using UV transilluminator (UVP Upland, CA 91786 U.S.A.) for $1 \mathrm{hr} 20$ mins at regular room temperature. After treatment, $5 \mu \mathrm{l}$ of $6 \mathrm{X}$ bromophenol blue was added to each tube. All samples were examined by gel electrophoresis on $1 \%$ agarose gel (containing ethidium bromide) in TAE buffer ( $\mathrm{pH} 8)$. The gel was then photographed under UV light. Untreated, cowpea DNA was lane along with untreated UV-irradiated DNA and extracts treated UV-irradiated sample.

\section{Statistical analysis}

All tests were conducted in triplicate. Data are reported as means \pm standard error (SE). Results were analyzed statically by using Microsoft Excel 2010.

\section{RESULTS AND DISCUSSION}

\section{Phytochemical analysis of methanol extract of Honeycrisp apple}

The phytochemical exploration validated the manifestation of alkaloids, flavonoids, glycosides, phenols, saponins, quinones, carboxylic acids, proteins and tannins (Table 1). Phenolic compounds, flavonoids, alkaloids and tannins are deliberated to hold great antioxidant

Table 1: Shows phytochemical constituents of methanol extract of Honeycrisp apple.

\begin{tabular}{cc|}
\hline Test & Methanol extract \\
\hline Alkaloid & ++ \\
Proteins & ++ \\
Tannins & ++ \\
Saponnins & + \\
Glycosides & +++ \\
Quinones & + \\
Flavonoids & +++ \\
Carboxylic acid & ++ \\
Phenols & +++ \\
\hline
\end{tabular}

Present (+), absent (-). 
potentials, which avert or can be used in the management of many diseases, comprising cancer. ${ }^{6,23,35}$ As a result, the existence of significant to realistic amounts of these phytochemicals can be linked with the promising significant antioxidant prospective of the apple. , $^{6,12,25}$

Table 1 displays phytochemical constituents of methanol extract of Honeycrisp apple. It was detected that all photochemical under investigation confirmed positive.

\section{Antioxidant activity of methanol extract from Honeycrisp apple}

The harmfulness and destruction caused by $\mathrm{NO}^{-}$with superoxide anion is increased as they retort to yield reactive peroxynitrite (ONOO), which hints to solemn lethal feedbacks with biomolecules such as protein, lipids and nucleic acids. ${ }^{5,30}$ In this research, the despicable inhibition was improved with cumulative concentration of the extract and the standard ascorbic acid was moderately more noticeable than that of the extract. The standard ascorbic acid and the extract has the highest $\%$ inhibition of $93.98 \%$ and $61.50 \%$ respectively for the highest concentration tested $(100 \mu \mathrm{g} / \mathrm{ml})$ (Figure 1). Reactive oxygen species, $\mathrm{NO}$ is also occupied in inflammation, cancer and other biological situations. ${ }^{6,24}$ The $\mathrm{NO}^{-}$scavenging activity of Honeycrisp apple may assist to capture the chain reactions introduced by additional cohort of $\mathrm{ONOO}^{-}$that is disadvantageous to human condition.

This illustrates that methanol extract had the ability to rummage nitric oxide radicals. The $\%$ inhibition increases with growing concentration in a measured quantity dependent way (Figure 1).

Additionally, the extract also revealed DPPH sifting action. DPPH is an unwavering free radical and has been useful widely in the assessment of the capacity of natural products to turn as free radical scavengers or hydrogen donors. ${ }^{21}$ Antioxidants whichever relocate an electron or a hydrogen atom to DPPH, thus cancelling out a number of DPPH molecules identical to that of hydroxyl groups. ${ }^{2}$ The standard ascorbic acid, tannic acid and the methanol extract has the highest \% inhibition of $56.68 \%$ for the highest concentration tested $(100 \mu \mathrm{g} / \mathrm{ml}), 44.06 \%$ for $80 \mu \mathrm{g} / \mathrm{ml}$ concentration tested and $40.92 \%$ for the highest concentration tested $(100 \mu \mathrm{g} / \mathrm{ml})$ respectively (Figure 2). This seems that Honeycrisp apple retains hydrogen-donating abilities to perform as an antioxidant. Centered on the figures achieved from this study, the scavenging abilities improved with collective concentration of the extract. The results give a picture that the extract had the very aptitude to scavenge DPPH radicals. The $\%$ inhibition increases with cumulative concentration in a measure dependent mode (Figure 2).

The $\mathrm{IC}_{50}$ is inversely proportional to the scavenging activity of the extract. The $\mathrm{IC}_{50}$ values of methanol extract from Honeycrisp apple varied from 10.30 to $36.29 \mu \mathrm{g} / \mathrm{ml}$ (Table 2) which indicates the high radical scavenging activity of sample. The $\mathrm{IC}_{50}$ were in the order: Ascorbic acid > Tannic acid > Honeycrisp apple and Ascorbic acid > Honeycrisp apple for DPPH \% inhibition activity and NO \% inhibition activity respectively (Table 2 ).

\section{Oxidative DNA damage protecting activity of methanol extract from Honeycrisp apple}

The UV photolysis of $\mathrm{H}_{2} \mathrm{O}_{2}$ involves the reaction between $\mathrm{H}_{2} \mathrm{O}_{2}$ and UV to form hydroxyl radical. The results showed complete degradation of genomic DNA from cowpea treated with UV indicated in lane 2 (Figure 3 ). The action of the apple extract on DNA damage was indicated in lanes 3 and 4, 7 and 8 for the extract and DNA alone and 5 and 6 for the

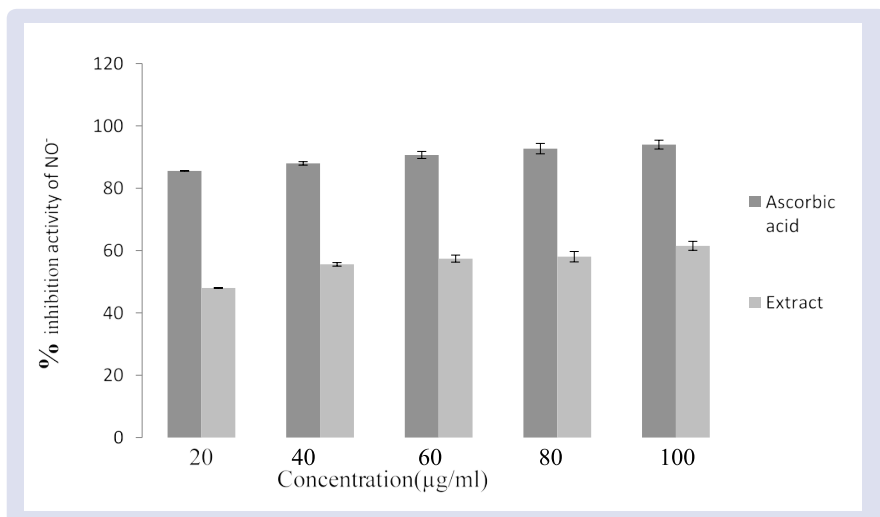

Figure 1: Displays the nitric oxide inhibition of the methanol extract of Honeycrisp apple and standard, ascorbic acid.

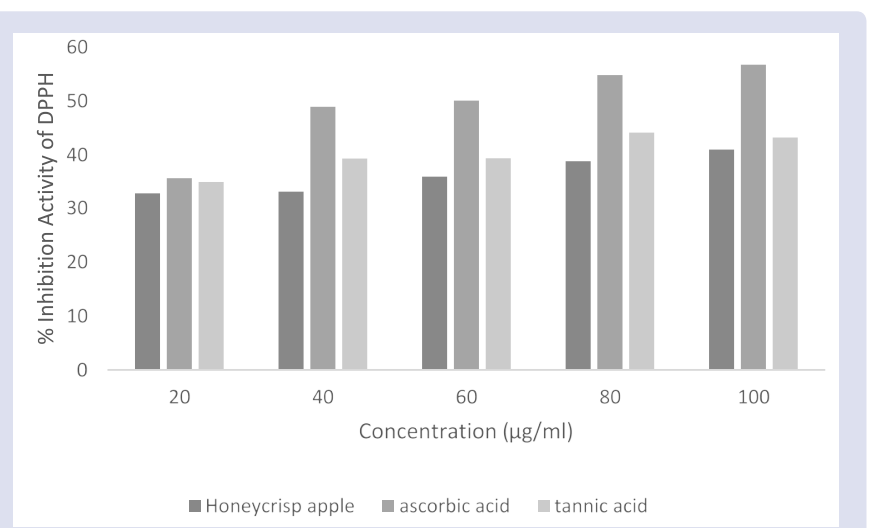

Figure 2: Displays DPPH - scavenging activity of methanol extract from Honeycrisp apple paralleled per standard ascorbic acid and tannic acids. 
Table 2: $I C_{50}$ values of free radical scavenging activities of methanol extract from Honeycrisp apple $(\mu \mathrm{g} / \mathrm{ml})$.

\begin{tabular}{ccc}
\hline Sample & DPPH & NO \\
\hline Honeycrisp apple & $36.29 \pm 1.67$ & $10.30 \pm 0.30$ \\
Ascorbic Acid & $49.18 \pm 1.86$ & $12.20 \pm 0.32$ \\
Tannic Acid & $40.14 \pm 0.7$ & ---- \\
\hline
\end{tabular}

Values represent the mean of three readings \pm standard deviation of the mean.

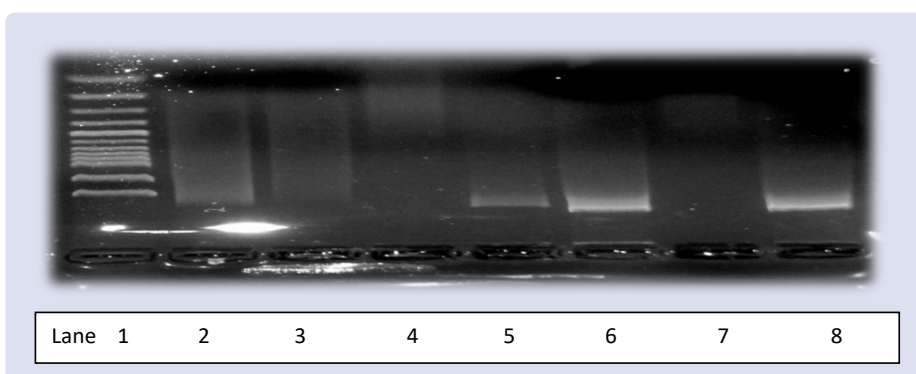

Figure 3: Expresses the electrophoretic arrangement of DNA from cowpea after UV-photolysis of hydrogen peroxides in the presence and absence Honeycrisp apple extract. Lane 1 : (marker), lane 2 : (DNA $+\mathrm{H}_{2} \mathrm{O}_{2}$ ), lane 3 : (DNA $+\mathrm{H}_{2} \mathrm{O}_{2}+20 \mu \mathrm{g} / \mathrm{ml}$ extract), lane $4:$ (DNA $+\mathrm{H}_{2} \mathrm{O}_{2}+100 \mu \mathrm{g} / \mathrm{ml}$ extract), lane $5:$ (DNA $+\mathrm{H}_{2} \mathrm{O}_{2}+20 \mu \mathrm{g} / \mathrm{ml}$ ascorbic acid), lane $6:\left(\right.$ DNA $+\mathrm{H}_{2} \mathrm{O}_{2}+100 \mu \mathrm{g} / \mathrm{ml}$ ascorbic acid), lane $7:$ (DNA $+100 \mu \mathrm{g} / \mathrm{ml}$ extract), lane $8:(D N A+20 \mu \mathrm{g} / \mathrm{ml}$ ).

standard ascorbic acid (Figure 3). From figure 3, it could be concluded that the extract and ascorbic acid showed some DNA protection ability, but the effect is not much seen when the concentrations were varied. The strength of the DNA damage was condensed on a concentration dependent manner of the extracts towards DNA which shows the shielding influence of the extract towards hydrogen peroxide made damage. The result suggests that methanol extract of Honeycrisp apple protect DNA through antioxidant activity and may be used in future to prevent cancer. ${ }^{7,20}$ The result agrees with other reports which indicate the potential of plants to protect against free radical-mediated DNA damage. ${ }^{7,14,27}$

\section{CONCLUSION}

In conclusion, this research exposed the presence of polyphenolics and some other phytochemicals in the methanol extract from Honeycrisp apple which also reflected in the free radical scavenging activity of this extract. Further, the extract conferred fortification against oxidative destruction. The antioxidant activity of Honeycrisp apple may possibly substantiate advance enquiry of its other constructive natural possessions and determine its protection.

\section{ACKNOWLEDGEMENT}

Not applicable.

\section{CONFLICTS OF INTEREST}

The authors declare no conflicts of interest.

\section{ABBREVIATIONS}

ONOO-: Reactive peroxynitrite; NO: Nitric oxide; UV light: Ultraviolet light; DPPH: 1,1-Diphenyl-2, picrylhydrazine; ROS: Reactive oxygen species.

\section{REFERENCES}

1. Ames BM, Shigenaga MK, Hagen TM. Oxidants, antioxidants and the degenerative diseases of aging. Proceedings of the National Academy Sciences. 1993:90:7915-22.
2. Barros L, Ferreira MJ, Queirros B, Ferreira ICF, Baptista P. Total phenlos, ascorbic acids, beta carotene and lycopene in Portuguese wild edible mushrooms and their antioxidants activities. Food Chemistry. 2007;103:413-9.

3. Cetkovic G, Canadanovic-Brunet J, Djilas S, Savatovic S, Mandic A, Tumbas V. Assessment of polyphenolic content and in vitro antiradical characteristics of apple pomace. Food Chem. 2008;109:340-7.

4. Chevion S, Roberts MA, Chevion M. The use of cyclic voltammetry for the evaluation of antioxidant capacity. Free Radical Biology and Medicine. 2000;28:860-70

5. Daniela M, Roberto C, Isabella NF, Nocente DC, Maria GD, Taddei F. From seed to cooked pasta: Influence of traditional and non-conventional transformation processes on total antioxidant capacity and phenolic acid content. International Journal of Food Sciences and Nutrition. 2008;69:1-24.

6. Darkwah WK Adinortey M, Weremfo A Phytochemical constituents and aromatic content of methanol and aqueous extracts of dissotis rotundifolia whole plant. South Asian Research Journal of Natural Products. 2018;1(1):1-5.

7. Darkwah WK, Ao Y, Adinortey MB, Weremfo A, Abrokwah FK, Afriyie E. Total phenolic, flavonoid and alkaloid contents, oxidative DNA damage protective and antioxidant properties of methanol and aqueous extracts of dissotis rotundifolia whole plant. Free Radicals and Antioxidants. 2018;8(2):82-8.

8. Diñeiro García Y, Suarez Valles B, Picinelli Lobo A. Phenolic and antioxidant composition of by-products from the cider industry: Apple pomace. Food Chem. 2009;117:731-8

9. Doyle JJ, Doyle JL. A rapid DNA isolation procedure for small quantities of fresh leaf tissue. Phytochemical Bulletin. 1987;19:11-5.

10. Drogoudi PD, Michailidis Z, Pantelidis G. Peel and flesh antioxidant content and harvest quality characteristics of seven apple. Cultivars Sci Hortic. 2008;115:149-53

11. Fukushima NS, Tsud, H. Carcinogenity and modification of the carcinogenic response by $\mathrm{BHA}, \mathrm{BHT}$ and other antioxidants. Critical Reviews in Toxicology. 1985;15:109-50.

12. Ghasemzadeh A, Jaafar $H Z$, Rahmat A. Antioxidant activities, total phenolics and flavonoids content in two varieties of Malaysia young ginger (Zingiber officinale Roscoe). Molecules (Basel, Switzerland). 2010;15:4324-33.

13. Grigoras CG, Destandau E, Fougère L, Elfakir C. Evaluation of apple pomace extracts as a source of bioactive compounds. Ind Crops Prod. 2013;49:794-804

14. Guha G, Rajkumar V, Mathew L, Kumar RA. The antioxidant and DNA protection potential of Indian tribal medicinal plants. Turkish Journal of Biology. 2011;35:233-42.

15. Halliwell B. Antioxidants in human health and disease. Annual Review of Nutrition. 1997;16:33-50. 
16. Halliwell B, Gutteridge JMC. Free radicals in biology and medicine. United Kingdom: Oxford University Press. 1999

17. Halliwell B, Gutteridge JMC. Free radicals in biology and medicine. Oxford, UK: Oxford University Press. 2003.

18. Harborne A. Phytochemical methods a guide to modern techniques of plant analysis, Springer Science and Business Media. 1998.

19. Jagetia GC, Rao SK, Baliga MS. The evaluation of nitric oxide scavenging activity of certain herbal formulations in vitro: A preliminary study. Phytotherapy research. 2004;18:561-5

20. Koomson DA, Kwakye BD, Darkwah WK, Odum B, Asamoah KA, Aidoo G. Phytochemical constituents, total saponins, alkaloids, flavonoids and vitamin $\mathrm{c}$ contents of ethanol extracts of five solanum torvum fruits. Pharmacog $\mathrm{J}$. 2018;10(5):946-50.

21. Liyana-Pathirana, CM, Shahidi F. Antioxidant properties of commercial soft and hard winter wheats (Triticum aestivum L.) and their milling fractions. J Sci Food Agric. 2006;86:477-85

22. LuY, Yeap FL. Antioxidant and radical scavenging activities of polyphenols from apple pomace. Food Chem. 2000;68:81-85.

23. Madhuri S, Pandey G. Some anticancer medicinal plants of foreign origin Current Science. 2008;96(6): 779-83.

24. Moncada S, Palmer R, Higgs E. Nitric oxide: physiology, pathophysiology and pharmacology, Pharmacological reviews. 1991;43:109-42.

25. Mustafa RA, Abdul Hamid A, Mohamed S, Bakar FA. Total phenolic compounds, flavonoids and radical scavenging activity of 21 selected tropical plants. Journal of food science. 2010;75:C28-35.

26. Pontais I, Treutter D, Paulin JP, Brisset MN. Erwinia amylovora modifies phenolic profiles of susceptible and resistant apple through its type III secretion system. Physiol Plant. 2008;132:262-71.

\section{GRAPHICAL ABSTRACT}

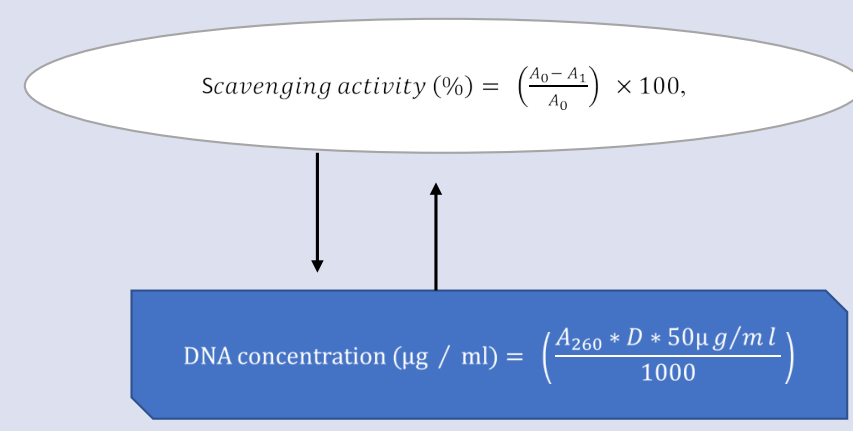

27. Russo AA, Izzo F, Borrelli M, Renis A, Vanella. Free radical scavenging capacity and protective effect of Bacopa monniera L. on DNA damage. Phytotherapy Research. 2003;17:870-5

28. Schieber A, Stintzing FC, Carle R. By -products of plant food processing as a source of functional compounds recent developments. Trends Food Sci Technol. 2001;12:401-13.

29. Shimada K, Fujikawa K, Yahara K, Nakamura T. Antioxidative properties of xanthan on the autoxidation of soybean oil in cyclodextrin emulsion. Journal of Agricultural and Food Chemistry. 1992;40:945-94

30. Keddari S, Benaoum N, BoufadiY, Belhocine M, Riazi A. Antioxidant activity and in vitro fermentation of dietary fiber extracts from durum wheat bran. Journal of Food and Nutrition Research. 2010:4(8):508-14.

31. Stone WL, Leclair I, Ponder T, Bagss G, Barret-Reis B. Infants discriminate between natural and synthetic vitamin E. American Journal of Clinical Nutrition. $1997 ; 77: 899-906$

32. Suárez B, Álvarez AL, Dineiro Garcia Y, Barrio G, Lobo D, Parra APF. Phenolic profiles, antioxidant activity and in vitro antiviral properties of apple pomace. Food Chem. 2010;120:339-42

33. Trease G, Evans W. A textbook of pharmacognosy academic press, London. $1998: 198: 22-40$

34. Wolfe KL, Kang X, He X, Dong M, Zhang Q, Liu RH. Cellular antioxidant activity of common fruits. J Agric Food Chem. 2008;56:8418-26.

35. Yao Y, Sang W, Zhou M, Ren G. Phenolic composition and antioxidant activities of 11 celery cultivars. Journal of Food Science. 2010:75:C9-13.

36. Devi KD, Punyarani K, Singh NS, Devi HS. An efficient protocol for total DNA extraction from the members of order Zingiberales. Suitable for diverse PCR based downstream applications. Springer Plus. 2013;2:669.

\section{ABOUT AUTHORS}

\section{SUMMARY}

- This report presents the qualitative phytochemical constituents and considers the in vitro free radicals scavenging activities of methanol extract from Honeycrisp apple.

- It tackles the activities based on nitric oxide assays and related, and oxidative DNA damage protection activity

- The DNA damage defensive potential of the extracts was also revealed, which could be used in cancer inhibition.

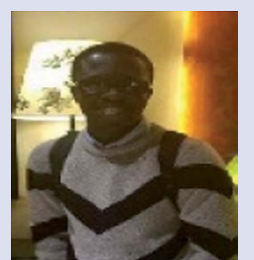

Williams Kweku Darkwah is an M.Sc. Student (advisor: ProfessorYanhui Ao) at Environmental Engineering Department, College of Environment, Hohai University, Nanjing, China. He received his BSc degree from University of Cape Coast, Cape Coast, Ghana. His research interests mainly focus on photocatalysis based water remediation technology using nanomaterials, and bioactivity of natural products.

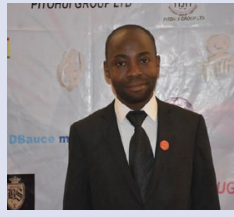

Matthew Nkoom received his BSc in Renewable Natural Resources with a major in environment and sustainability from the University for Development Studies, Ghana in 2012. He was a teaching assistant at his department from 2012 to 2013. He also holds an MSc in Environmental Science with a major in environmental toxicology from Wageningen University, Netherlands in 2015. He is currently a doctoral candidate at the College of environment, Hohai University, China, under the supervision of Prof. Guanghua $\mathrm{Lu}$. His research is on the toxicity of pharmaceuticals and personal care products in the aquatic environment.

Cite this article: Darkwah WK, Nkoom M. Free Radicals Scavenging Activity and Oxidative DNA Damage Protecting Property of Methanol Extract from Honeycrisp Apple. Pharmacog J. 2019;11(4):694-8. 